\title{
Comparison of two fluorescent antibody techniques (FATs) for detection and quantification of Renibacterium salmoninarum in coelomic fluid of spawning chinook salmon Oncorhynchus tshawytscha
}

\author{
D. G. Elliott*, C. L. McKibben \\ U.S. Geological Survey, Biological Resources Division, Northwest Biological Science Center, 6505 N.E. 65 th Street, \\ Seattle, Washington 98115, USA
}

\begin{abstract}
Two versions of the fluorescent antibody technique (FAT) were compared for detection and quantification of Renibacterium salmoninarum in coelomic fluid samples from naturally infected spawning chinook salmon Oncorhynchus tshawytscha. For the membrane filtration-FAT (MF-FAT), trypsin-treated samples were passed through $0.2 \mu \mathrm{m}$ polycarbonate filters to concentrate bacteria for direct enumeration by immunofluorescence microscopy. For the smear-FAT (S-FAT), samples were centrifuged at $8800 \times \mathrm{g}$ for $10 \mathrm{~min}$ and the pelleted material was smeared on slides for immunofluorescence staining. Detected prevalences of Renibacterium salmoninarum were 1.8 to 3.4 times higher by the MF-FAT than by the S-FAT; differences were significant at $p \leq 0.0002$. The S-FAT consistently detected $R$. salmoninarum only in samples with calculated bacterial concentrations $\geq 2.4 \times 10^{3} \mathrm{cells} \mathrm{ml}^{-1}$ by MF-FAT testing. Increasing the area examined on a filter or slide from 50 to 100 microscope fields at $1000 \times$ magnification resulted in the detection of a maximum of $4 \%$ additional positive samples by the MF-FAT and $7 \%$ additional positive samples by the S-FAT. In individual samples for which bacterial counts were obtained by both the MF-FAT and the S-FAT, the counts averaged from 47 times $( \pm 30$ SD) to 175 times $( \pm 165 \mathrm{SD})$ higher by the MF-FAT. Centrifugation of samples at $10000 \times g$ for $10 \mathrm{~min}$ resulted in a 4 -fold increase in mean bacterial counts by the S-FAT compared with a 10-min centrifugation at $2000 \times g$, but the highest calculated bacterial concentration obtained by S-FAT testing was more than 6-fold lower than that obtained for the same sample by MF-FAI testing. Because of its greater sensitivity, the MF-FAT is preferable to the S-FAT for use in critical situations requiring the detection of low numbers of $R$. salmoninarum.
\end{abstract}

KEY WORDS: Renibacterium salmoninarum - Broodstock screening - Fluorescent antibody technique (FAT) - BKD detection

\section{INTRODUCTION}

Bacterial kidney disease (BKD) is a significant obstacle to the successful artificial propagation of salmonids, particularly Pacific salmon Oncorhynchus spp. (Fryer \& Lannan 1993). Control of this chronic systemic disease is complicated by the dual modes of transmission of the causative agent Renibacterium salmoninarum, which can be transmitted both vertically (Evelyn et al.

•E-mail; diane_elliott@nbs.gov
1984, 1986) and horizontally (Mitchum \& Sherman 1981, Bell et al. 1984). Evidence suggests a positive correlation between the severity of infection in the female parent and the frequency and severity of infection in the progeny (Pascho et al. 1991), but the processes of vertical transmission of $R$. salmoninarum are not understood. Although some $R$. salmoninarum cells may become incorporated into developing oogonia (Bruno \& Munro 1986), transmission also may occur by contact of the eggs with contaminated coelomic (ovarian) fluid (Evelyn et al. 1986, Lee \& Evelyn 1989). 
Increased knowledge of the mechanisms of vertical transmission of $R$. salmoninarum is necessary for the development of more effective methods for preventing its occurrence.

Several rapid immunological methods have been used for detection of Renibacterium salmoninarum in tissues and body fluids of spawning fish. Such tests include the enzyme-linked immunosorbent assay (ELISA; Pascho et al. 1987, 1991), the membrane filtration-fluorescent antibody technique (MF-FAT; Elliott \& Barila 1987, Pascho et al. 1987, 1991), and the smear FAT (S-FAT; Lee \& Gordon 1987a, Armstrong et al. 1989). The ELISA detects soluble antigens produced by $R$. salmoninarum, whereas the FAT enables the enumeration of bacterial cells in samples. The ELISA can be used for rapid testing of samples from large numbers of fish, but the results of one study indicated that this test consistently detected the presence of $R$. salmoninarum antigen only in coelomic fluid samples with bacterial counts $>1 \times 10^{5} \mathrm{ml}^{-1}$ as determined by the MF-FAT (Pascho et al. 1991). Renibacterium salmoninarum concentrations $<1 \times 10^{2}$ bacteria $\mathrm{ml}^{-1}$ can be detected in coelomic fluid by the MF-FAT (Elliott \& Barila 1987). However, this procedure, which involves the concentration of $R$. salmoninarum from individual samples on membrane filters for direct enumeration by immunofluorescence microscopy, can be labour-intensive. The S-FAT, a procedure in which samples are centrifuged and the pelleted material is smeared on slides for immunofluorescence staining, can be performed more rapidly than the MF-FAT, but may be less sensitive. Lee \& Gordon (1987b) reported higher $R$. salmoninarum detection rates in coelomic fluid samples tested by the MF-FAT compared with the S-FAT, but they did not describe the procedures used for processing and analyzing samples for the S-FAT.

The purpose of our study was to determine the relative sensitivities of the MF-FAT and the S-FAT for the detection of Renibacterium salmoninarum in the coelomic fluid of naturally infected chinook salmon Oncorhynchus tshawytscha. The effect of centrifugation speed on the sensitivity of the S-FAT was also investigated.

\section{MATERIALS AND METHODS}

Coelomic fluid samples. Coelomic fluid samples were obtained from spawning spring chinook salmon at Dworshak National Fish Hatchery (NFH), U.S. Fish and Wildlife Service (USFWS), Ahsahka, Idaho, USA, in 1988 and at Carson NFH (USFWS), Carson, Washington, USA, in 1994. The samples were frozen at $-70^{\circ} \mathrm{C}$ until use.
MF-FAT. The MF-FAT procedure of Elliott \& Barila (1987), as modified by Pascho et al. (1991), was used for these experiments. To disperse and digest cellular debris, a $0.5 \mathrm{ml}$ coelomic fluid sample was mixed with $0.5 \mathrm{ml}$ each of the following solutions: (1) phosphatebuffered saline containing $100 \mathrm{mg} \mathrm{l}^{-1}$ thimerosal as a preservative (PBS, $0.01 \mathrm{M}$ phosphate, $\mathrm{pH} 7.1$ ) and with $0.5 \%$ (by volume) Triton $X-100$ added (PBS-Triton), and (2) a trypsin solution prepared by mixing trypsin powder (Difco 1:250, Difco Laboratories, Detroit, MI, USA) at $10 \mathrm{~g} \mathrm{l}^{-1}$ in distilled water at $4^{\circ} \mathrm{C}$, then clarifying the mixture by filtration through Whatman No. 1 filter paper (Whatman, Maidstone, England) followed by filtration through a $0.2 \mu \mathrm{m}$ filter. The mixture of coelomic fluid, PBS-Triton, and trypsin solution was heated at $50^{\circ} \mathrm{C}$ for $10 \mathrm{~min}$, then filtered through a $13 \mathrm{~mm}$ diameter, $0.2 \mu \mathrm{m}$ pore size polycarbonate filter (Nuclepore Corp., Cambridge, MA, USA) backed by a $5.0 \mu \mathrm{m}$ nylon support filter (Micron Separations, Inc., Westboro, MA, USA) in a syringe-mounted disposable pop-top holder (Nuclepore). Filters were then rinsed with $3 \mathrm{ml}$ of PBSTriton delivered by syringe. For immunofluorescence staining, $100 \mu \mathrm{l}$ of fluorescein isothiocyanate-(FITC) conjugated, affinity-purified immunoglobulin to Renibacterium salmoninarum (Kirkegaard and Perry Laboratories, Inc., Gaithersburg, MD, USA) was placed on each filter for $1 \mathrm{~h}$ at room temperature. The conjugate was used at a working dilution of 1:40 (v/v) in PBS and was filtered through a $0.2 \mu \mathrm{m}$ filter before use. Each filter was rinsed as previously described and counterstained with $1 \mathrm{ml}$ of Eriochrome black T (Sigma, St. Louis, MO, USA) prepared at $500 \mathrm{mg} \mathrm{l}^{-1}$ in PBS and filtered through Whatman No. 1 and Whatman No, 42 filter papers before initial use. Filters were removed from the holders, placed on glass microscope slides and air dried; cover glasses were mounted with glycerolDABCO mounting medium (Johnson et al. 1982).

Positive control filters were prepared with coelomic fluid samples that had tested positive for Renibacterium salmoninarum by the ELISA and by the MFFAT using both monoclonal antibodies and polyclonal antiserum. The control samples originated from spawning populations of spring chinook salmon that also had tested positive for $R$. salmoninarum by bacteriological culture. Because of a lack of known $R$. salmoninarum-negative populations of spring chinook salmon, negative control filters were prepared using reagents only, with sample diluent substituted for the coelomic fluid sample. These controls were used to ensure that reagents and filters did not become contaminated during MF-FAT procedures.

Each filter was examined by epifluorescence microscopy at $1000 \times$ magnification. A Zeiss WL microscope with a Neofluar $100 \times$ objective was used for all experiments except the second comparison of the MF-FAT 
and S-FAT, for which a Zeiss Axiophot microscope with a Zeiss Planapochromat $100 \times$ objective was used. Both microscopes were equipped with filter sets for FITC. Bacteria showing specific fluorescence and having morphological characteristics consistent with Renibacterium salmoninarum were counted in 50 and 100 microscope fields on each filter. These counts were converted to cells per milliliter of the original coelomic fluid sample according to the formula of Ecker \& Lockhart (1959) as adapted by Elliott \& Barila (1987): cells $\mathrm{ml}^{-1}=($ conversion factor $) \times$ (dilution factor $) \times($ no. cells counted)/no. fields counted, where the conversion factor is the filtering surface area divided by the area of a single field at the magnification used.

S-FAT. Unless otherwise specified, coelomic fluid samples were centrifuged in microcentrifuge tubes (Sarstedt, Inc., Newton, NC, USA) for $10 \mathrm{~min}$ at $8800 \times$ $g$ in an Eppendorf 5413 centrifuge (Brinkmann Instruments, Inc., Westbury, NY, USA) equipped with a horizontal rotor. The supernatant was discarded, then the pellet was removed with a calcium alginate swab /Calgiswab Type 4, Spectrum Laboratories, Los Angeles, CA, USA) moistened with PBS (0.01 M, pH 7.1). The pelleted material was smeared thinly on both wells of a 2-well microscope slide (Cel-Line Associates, Newfield, NJ, USA; $8 \mathrm{~mm}$ diameter wells). The smears were air dried and then heat fixed by passing them over a flame. The slides were stained with the same preparation and working dilution of FITC-conjugated antiRenibacterium salmoninarum immunoglobulin as used for the MF-FAT. A $50 \mu$ volume of the conjugate was placed on each well of a slide, then the slide was incubated in a humid chamber at room temperature for $1 \mathrm{~h}$. To minimize sloughing of the smears, slides were rinsed carefully with PBS, then flooded with PBS for $10 \mathrm{~min}$. The slides were counterstained by flooding them for $60 \mathrm{~s}$ with an aqueous suspension $(1: 60 \mathrm{w} / \mathrm{v})$ of Eriochrome black $T$, then the slides were rinsed as previously described. After a final rinse with distilled water, the slides were air dried and cover glasses were mounted with glycerol-DABCO medium. Positive control slides were prepared from the same known positive coelomic fluid samples as were used for the MFFAT. Each slide was examined by epifluorescence microscopy, and fluorescing bacteria that met the criteria described for the MF-FAT were counted in 50 microscope fields ( $1000 \times$ magnification) per well, for a total of 100 fields per slide. The counts were converted to cells per milliliter of the original coelomic fluid sample according to the formula of Ecker \& Lockhart (1959) as previously described, but the total surface area of the slide wells was substituted for the total filtering surface area in the formula.

Comparison of MF-FAT and S-FAT. For the first experiment, coelomic fluid samples from 27 individual chinook salmon spawned at Dworshak NFH were used. These samples had been tested 3 yr previously by the MF-FAT, and had shown a range of Renibacterium salmoninarum concentrations from no detected bacteria to about $1.5 \times 10^{9}$ cells $\mathrm{ml}^{-1}$ when 150 microscope fields per filter were examined. Each sample was tested by the S-FAT and retested by the MF-FAT; a $0.5 \mathrm{ml}$ volume of coelomic fluid was used for each test. The samples were coded so that they could be examined without bias.

The second experiment used coelomic fluid samples from 151 individual Carson NFH chinook salmon that had not been tested previously by either the MF-FAT or the S-FAT. Twenty-nine of the samples were taken from fish that had grossly visible kidney lesions characteristic of $B K D$; the remaining samples were from asymptomatic fish. Subsamples of $0.5 \mathrm{ml}$ each were examined by each test. Based on the results of the first experiment, the S-FAT procedure was modified to further enhance retention of the smears on the slides. After heat-fixing a smear, it was dipped in acetone for 1 min, and allowed to drain. The PBS rinses were reduced from $10 \mathrm{~min}$ to $5 \mathrm{~min}$.

Effect of centrifugation speed on S-FAT counts. A coelomic fluid sample was pooled from 10 female chinook salmon spawned at Dworshak NFH. By MF-FAT testing, the Renibacterium salmoninarum concentration in this sample was $5.4 \times 10^{5}$ cells $\mathrm{ml}^{-1}$. Samples were centrifuged at 2000,4000,6000,8000, and 10000 $\times g$ for $10 \mathrm{~min}$ in a Sorvall RC-5B centrifuge (Du Pont Co., Wilmington, DE, USA) equipped with a Sorvall SH-MT horizontal rotor. Four 0.5-ml subsamples were centrifuged at each speed. Bacteria were counted in 100 microscope fields per slide as previously described.

Statistical analysis. The Fisher exact test (Zar 1974) was used to compare the relative prevalences of Renibacterium salmoninarum detected in coelomic fluid samples by the MF-FAT and the S-FAT, and to compare the relative prevalences of the bacterium detected by a given FAT procedure when 50 and 100 microscope fields were examined on a slide or filter.

\section{RESULTS}

\section{Comparison of MF-FAT and S-FAT}

For the first experiment, examination of 100 rather than 50 microscope fields per sample did not increase the number of coelomic fluid samples positive for Renibacterium salmoninarum by the MF-FAT, and did not result in a significant increase $(p=0.57)$ in positive samples by the S-FAT (Table 1). However, the number of samples positive for $R$. salmoninarum was higher $(\mathrm{p}<$ 
Table 1. Comparison of the MF-FAT and S-FAT for detection and quantification of Renibacterium salmoninarum in coelomic fluid of chinook salmon Oncorhynchus tshawytscha from Dworshak National Fish Hatchery, Idaho, USA. The 27 samples were selected because they had shown a wide range of $R$. salmoninarum concentrations (or were negative) by previous MF-FAT testing. The calculated detection limit for the MF-FAT in this experiment was 128 bacteria $\mathrm{ml}^{-1}$ when 50 fields were examined and 64 bacteria $\mathrm{ml}^{-1}$ when 100 fields were examined. The calculated detection limit for the S-FAT was 160 bacteria $\mathrm{ml}^{-1}$ when 50 fields were examined and 80 bacteria $\mathrm{ml}^{-1}$ when 100 fields were examined. TNTC: bacteria too numerous to count (see footnote). Significant difference at $\mathrm{p}<0.0001$ and ${ }^{*} \mathrm{p}<0.0001$

\begin{tabular}{|c|c|c|c|c|}
\hline \multirow[t]{3}{*}{ Female no. } & \multicolumn{4}{|c|}{ No. of $R$. salmoninarum counted } \\
\hline & \multicolumn{2}{|c|}{50 fields } & \multicolumn{2}{|c|}{100 fields } \\
\hline & MF-FAT & S-FAT & MF-FAT & S-FAT \\
\hline 82 & 0 & 0 & 0 & 0 \\
\hline 742 & 0 & 0 & 0 & 0 \\
\hline 822 & 0 & 0 & 0 & 0 \\
\hline 1208 & 1 & 0 & 1 & 0 \\
\hline 1216 & 1 & 0 & 1 & 0 \\
\hline 850 & 1 & 0 & 2 & 0 \\
\hline 1158 & 1 & 0 & 2 & 0 \\
\hline 786 & 1 & 0 & 3 & 0 \\
\hline 854 & 1 & 0 & 3 & 0 \\
\hline 998 & 1 & 0 & 3 & 0 \\
\hline 800 & 3 & 0 & 4 & 0 \\
\hline 1100 & 4 & 0 & 4 & 0 \\
\hline 746 & 2 & 0 & 5 & 0 \\
\hline 852 & 3 & 0 & 7 & 0 \\
\hline 928 & 5 & 0 & 11 & 0 \\
\hline 1058 & 9 & 0 & 12 & 0 \\
\hline 834 & 11 & 0 & 17 & 0 \\
\hline 952 & 15 & 0 & 38 & 1 \\
\hline 798 & 33 & 0 & 72 & 0 \\
\hline 964 & 40 & 1 & 86 & 1 \\
\hline 762 & 80 & 0 & 154 & 1 \\
\hline 32 & 358 & 17 & 714 & 27 \\
\hline 1196 & 316 & 4 & 721 & 11 \\
\hline $\begin{array}{l}112,122 \\
704,172^{\circ}\end{array}$ & TNTC & TNTC & TNTC & TNTC \\
\hline $\begin{array}{l}\text { Total no. } \\
\text { positive }(\%)\end{array}$ & $24(89 \%)^{\circ}$ & $7(26 \%)^{\prime}$ & $24(89 \%)^{\cdots}$ & $9(33 \%) \cdot$ \\
\hline $\begin{array}{l}\text { aPrevious } \mathrm{Ml} \\
8.9 \times 10^{6} \mathrm{cel} \\
10^{8} \text { cells ml }\end{array}$ & $\begin{array}{l}\text {-FAT count } \\
\mathrm{s} \mathrm{ml}^{-1}, 122 \\
\text {, and } 172=\end{array}$ & $\begin{array}{l}\text { for these } \\
4.7 \times 10^{7} \\
1.5 \times 10^{9} \mathrm{C}\end{array}$ & $\begin{array}{l}\text { amples wer } \\
\text { eells } \mathrm{ml}^{-1}, 70 \\
\text { ells } \mathrm{ml}^{-1}\end{array}$ & $\begin{array}{l}\text { e: } 112= \\
4=7.0 \times\end{array}$ \\
\hline
\end{tabular}

0.0001 ) by the MF-FAT than by the S-FAT regardless of the number of microscope fields examined per filter or slide (Table 1). Seventeen more samples (a $63 \%$ difference in prevalence) were positive by the MF-FAT than by the S-FAT when 50 microscope fields were examined, and 15 more samples (a 56\% difference in prevalence) were positive by the MF-FAT than by the S-FAT when 100 microscope fields were examined. Renibacterium salmoninarum were detected by the S-FAT only in samples for which the MF-FAT counts were $\geq 40$ bacteria in 50 fields or $\geq 38$ bacteria in 100 fields, represent- ing calculated concentrations (by the MF-FAT) of $5.1 \times$ $10^{3}$ and $2.4 \times 10^{3}$ cells $\mathrm{ml}^{-1}$, respectively. For samples in which $R$. salmoninarum were countable by both the MF-FAT and the S-FAT (Table 1), the counts of bacteria on the filters averaged 47 times higher ( $\pm 30 \mathrm{SD}$ ) than counts on the corresponding slides when 50 microscope fields were examined (3 samples), and averaged 74 times higher ( $\pm 51 \mathrm{SD}$ ) when 100 microscope fields were examined ( 5 samples).

Because of changes made in the MF-FAT procedures, this experiment was not intended as a direct comparison between the present MF-FAT analysis and that done on the same coelomic fluid samples 3 yr earlier. Nevertheless, the prevalence of Renibacterium salmoninarum-positive samples detected by the present MF-FAT after prolonged sample storage at $-70^{\circ} \mathrm{C}$ (with additional thawing and freezing of some samples between analyses) was not significantly different ( $p=$ 0.48 ) from the prevalence $(82 \%)$ detected by the earlier MF-FAT. One sample that tested positive by the earlier procedure was negative by the present analysis, and 3 samples that tested negative by the earlier procedure were positive by the present analysis. These differences were observed in samples with $<10$ bacteria counted in 100 microscope fields (present test) or 150 microscope fields (previous test); all samples with higher bacterial counts were positive in both studies. Among samples testing positive by both MF-FAT analyses, correlation of $R$. salmoninarum counts was high $\left(\mathrm{r}^{2}=0.957\right)$.

In the second experiment, examination of 100 microscope fields rather than 50 fields for each sample resulted in small increases in the numbers of coelomic fluid samples positive for Renibacterium salmoninarum by both FATs (Table 2), but the increases were not significant for either the MF-FAT $(p=0.57)$ or the S-FAT $(p=0.90)$. However, comparison of the MF-FAT to the S-FAT showed significantly more samples positive by the MF-FAT than by the S-FAT when either 50 microscope fields ( $p=0.0002$ ) or 100 microscope fields $(\mathrm{p}<0.0001)$ were examined (Table 2). The MF-FAT detected 32 more positive samples than the S-FAT (a $21 \%$ difference in prevalence) when 50 microscope fields were examined, and 35 more positive samples than the S-FAT (a $24 \%$ difference in prevalence) when 100 microscope fields were examined. All samples that were positive for $R$. salmoninarum by the S-FAT also were positive by the MF-FAT. Single $R$. salmoninarum were detected by the S-FAT in samples showing as few as 3 bacteria in 100 fields and 5 bacteria in 50 fields by the MF-FAT. However, the bacterium was detected consistently by the S-FAT only in samples for which counts by the MF-FAT were $\geq 262$ cells in 100 fields and $\geq 420$ cells in 50 fields, representing calculated concentrations (by the MF-FAT) of $9.8 \times 10^{3}$ cells $\mathrm{ml}^{-1}$ 
and $3.1 \times 10^{4}$ cells $\mathrm{ml}^{-1}$, respectively. In 13 individual samples for which bacterial counts were obtained by both the MF-FAT and the S-FAT, the counts averaged 175 times higher $( \pm 165 \mathrm{SD}$ ) by the MF-FAT compared with the S-FAT when 50 microscope fields were examined and 174 times higher $( \pm 139 \mathrm{SD}$ ) by the MF-FAT when 100 microscope fields were examined.

Among the 29 coelomic fluid samples taken from fish with visible kidney lesions characteristic of BKD, 28 (97\%) were positive for Renibacterium salmoninarum by the MF-FAT and 25 (86\%) were positive by the SFAT. More than 50 bacteria were observed in 50 or 100 microscope fields in samples from 26 of the lesioned fish positive by the MF-FAT and in samples from 23 of the lesioned fish positive by the S-FAT.

\section{Effect of centrifugation speed on S-FAT counts}

The number of bacteria detected by the S-FAT increased as the centrifugation speed increased (Fig, 1). Mean bacterial counts were more than 4 times greater for subsamples centrifuged at $10000 \times g$ for $10 \mathrm{~min}$ than in samples centrifuged at $2000 \times g$ or $4000 \times g$ for $10 \mathrm{~min}$. The coefficient of variation (CV) for the mean bacterial counts at a given centrifugation speed ranged from $28 \%$ at $8000 \times g$ to $64 \%$ at $6000 \times g$. The highest calculated Renibacterium salmoninarum concentration obtained by S-FAT testing $\left(8.7 \times 10^{3}\right.$ cells $\left.\mathrm{ml}^{-1}\right)$ was more than 6 -fold lower than that obtained for the same sample by MF-FAT testing.

Table 2. Comparison of the MF-FAT and the S-FAT for detection and enumeration of Renibacterium salmoninarum in 151 coelomic fluid samples from chinook salmon Oncorhynchus tshawytscha at Carson National Fish Hatchery, Washington. USA. The samples had not been tested previously by either FAT The calculated detection limit for the MF-FAT in this experiment was 75 bacteria $\mathrm{ml}^{-1}$ when 50 fields were examined and 37 bacteria $\mathrm{ml}^{-1}$ when 100 fields were examined. The calculated detection limit for the S-FAT was 105 bacteria $\mathrm{ml}^{-1}$ when 50 fields were examined and 53 bacteria $\mathrm{ml}^{-1}$ when 100 fields were examined. Significant difference at $\cdot p=$ 0.0002 and $" p<0.0001$

\begin{tabular}{|lcccc|}
\hline \multirow{2}{*}{$\begin{array}{l}\text { Total no. } \\
\text { cells detected }\end{array}$} & \multicolumn{4}{c}{ No. samples in category (\%) } \\
& MF-FAT & S-FAT & MF-FAT & S-FAT \\
& & & & \\
& $78(52 \%)$ & $110(73 \%)$ & $73(48 \%)$ & $108(72 \%)$ \\
0 & $27(18 \%)$ & $10(7 \%)$ & $27(18 \%)$ & $10(7 \%)$ \\
$1-10$ & $2(1 \%)$ & $2(1 \%)$ & $5(3 \%)$ & $4(2 \%)$ \\
$11-25$ & $3(2 \%)$ & 0 & $1(1 \%)$ & 0 \\
$26-50$ & $41(27 \%)$ & $29(19 \%)$ & $45(30 \%)$ & $29(19 \%)$ \\
$>50$ & $73(48 \%)^{\circ}$ & $41(27 \%)^{\circ}$ & $78(52 \%)^{\circ}$ & $43(28 \%)^{*}$ \\
Total no. & & & & \\
positive (\%) & & & & \\
\hline
\end{tabular}

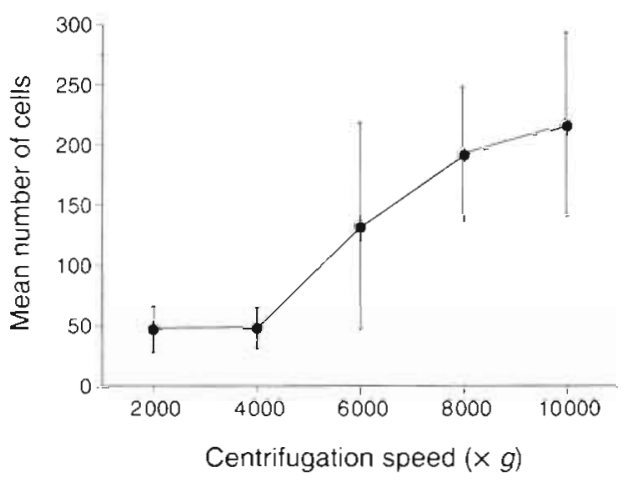

Fig. 1. Mean number ( $\pm \mathrm{SD}$ ) of Renibacterium salmoninarum cells counted in 100 microscope fields ( $1000 \times$ magnification) from coelomic fluid samples centrifuged at selected speeds for $10 \mathrm{~min}$ and examined by the S-FAT. Coelomic fluid pooled from 10 female chinook salmon Oncorhynchus tshawytscha naturally infected with $R$. salmoninarum was used; 4 subsamples were centrifuged at each speed

\section{DISCUSSION}

Renibacterium salmoninarum detection rates were 1.8 to 3.4 times higher by the MF-FAT than by the SFAT in our study. These findings were similar to those of Lee \& Gordon (1987b), who reported a 3-fold increase in the rate of detection of $R$. salmoninarum in coelomic fluid samples by an indirect MF-FAT in comparison to the S-FAT. Because Lee \& Gordon (1987b) did not describe procedures such as centrifugation speed and time used for their S-FAT, direct comparisons with our S-FAT results are difficult.

In the present comparison, both FATs detected Renibacterium salmoninarum in the coelomic fluid from most fish showing grossly visible kidney lesions characteristic of $\mathrm{BKD}$. The single lesioned fish that was negative by the MF-FAT also tested negative (both kidney and coelomic fluid) by an ELISA, suggesting that the lesion had a cause other than BKD.

Several factors may have contributed to the lower sensitivity of the S-FAT compared to the MF-FAT. The results of the centrifugation experiment suggested that not all of the bacteria were pelleted by centrifugation for $10 \mathrm{~min}$ at speeds up to $10000 \times \mathrm{g}$, and that higher speeds or longer centrifugation times would be required for more complete pelleting of the bacteria. Bacteria may also have been retained on the swabs or may have become detached from the slides during the staining or rinsing steps. Because all steps of the MFFAT are completed while the filters are retained in syringe-mounted holders, losses of bacteria are minimized (Elliott \& Barila 1987).

Increasing the area examined on a filter or slide from 50 microscope fields to 100 microscope fields did not greatly increase the Renibacterium salmoninarum 
detection rate by either the S-FAT or MF-FAT. The change in the number of fields examined resulted in a maximum difference in the detected $R$. salmoninarum prevalence of only $4 \%$ by the MF-FAT and $7 \%$ by the S-FAT.

The variability in S-FAT results, as evidenced in our study by the high CVS in the centrifugation experiment and inconsistent detection of Renibacterium salmoninarum by the S-FAT when MF-FAT counts were as high as 215 cells in 100 microscope fields, was similar to that reported by other authors. Armstrong et al. (1989) described the testing of coelomic fluid samples from 184 chinook salmon by 2 independent laboratories using an S-FAT in which samples were centrifuged at $10000 \times g$ for $10 \mathrm{~min}$. The pellets were resuspended in the small amount of remaining coelomic fluid, then thin smears were made on slides and subsequently stained by an indirect FAT. When the observation of one or more cells in 50 microscope fields at $1000 \times$ magnification was considered a positive result, agreement between the results of the 2 laboratories could be explained entirely by chance. When only those samples with more than 50 cells observed in 50 fields were regarded as positive, agreement between the results of the 2 laboratories was considered statistically significant, but the level of agreement was deemed unsatisfactory for a population screening test. From comparisons with bacteriological culture, Armstrong et al. (1989) estimated that about $60 \%$ of the S-FAT results in their study were falsely negative.

Although our experiments did not compare the variability of repeated MF-FAT counts with that of repeated S-FAT counts, the results of previous studies indicate that the variability of MF-FAT counts is lower. Elliott \& Barila (1987) filtered 10 subsamples of a coelomic fluid sample pooled from Renibacterium salmoninarum-positive fish (similar to the sample used for our S-FAT centrifugation test), and reported a CV of about $7 \%$ when 100 microscope fields were examined per filter by the MF-FAT. Lee \& Gordon (1987b) prepared 3 filters from a broth culture of $R$. salmoninarum, and observed a CV of about $5 \%$ for counts of 100 microscope fields per filter by an indirect MF-FAT. Both Elliott \& Barila (1987) and Lee \& Gordon (1987b) reported increased CVs when fewer fields were examined per filter, or after 2 -fold serial dilutions of samples were made before filters were prepared. Nevertheless, the CVs for MF-FAT counts in those studies remained below $20 \%$ even when samples were diluted $1: 16(\mathrm{v} / \mathrm{v})$ before filtration and only 50 fields per filter were examined, whereas $28 \%$ was the lowest $\mathrm{CV}$ observed in the present study for S-FAT counts of 100 microscope fields per slide on 4 slides. Elliott \& Barila (1987) and Lee \& Gordon (1987b) also observed good corre- spondence between MF-FAT counts and plate counts of $R$. salmoninarum broth cultures, with slightly higher numbers of bacteria detected by the MF-FAT.

Even though it is more sensitive than the S-FAT, the present MF-FAT procedure can be more labour-intensive and time-consuming for the testing of large numbers of samples. Modifications should be considered, including the use of inorganic filters that would allow more rapid filtration of samples (Jones et al. 1989), or the use of manifolds that would enable the simultaneous filtration of multiple samples (S. Foott, U.S. Fish and Wildlife Service, California, pers. comm.).

The MF-FAT and other techniques are now being used to investigate the relation between Renibacterium salmoninarum concentrations in coelomic fluid and vertical transmission of the bacterium. Evidence suggests that the probability of vertical transmission increases with increasing concentrations of $R$. salmoninarum in the coelomic fluid (Lee \& Evelyn 1989, Pascho et al. 1991). Nevertheless, transmission of the organism from fish with extremely low infection levels may occur. The bacterium has been detected by the polymerase chain reaction (PCR) in eggs from female chinook salmon that had tested negative for $R$. salmoninarum infection by both the ELISA and the MF-FAT (Brown et al. 1994).

The greater sensitivity of the MF-FAT compared to the S-FAT indicates that the MF-FAT would be preferable for use in situations such as inspections requiring the detection of low numbers of bacteria. Cross-reactions of other bacterial species with antisera prepared against Renibacterium salmoninarum have been reported (Bullock et al. 1980, Austin et al. 1985, Yoshimizu et al. 1987. Brown et al. 1995), so the inclusion in any FAT of control material from known $R$. salmoninarum-positive fish is necessary for comparison of cell morphology and staining properties of bacteria in test and control samples. Because neither the MF-FAT or the S-FAT can distinguish live from dead $R$. salmoninarum, culture of important samples may be advisable for confirmation of viability.

Acknowledgements. The authors thank Ronald Pascho and James Winton for critical review of the manuscript. This research was supported by the U.S. Fish and Wildlife Service, the National Biological Service, and the Biological Resources Division of the U.S. Geological Survey.

\section{LITERATURE CITED}

Armstrong RD, Martin SW, Evelyn TPT, Hicks B, Dorward WJ, Ferguson HW (1989) A field evaluation of an indirect fluorescent antibody-based broodstock screening test used to control the vertical transmission of Renibacterium salmoninarum in chinook salmon (Oncorhynchus tshawytscha). Can J Vet Res 53:385-389 
Austin B, Bucke D, Feist S, Rayment J (1985) A false positive reaction in the indirect fluorescent antibody test for Renibacterium salmoninarum with a 'coryneform' organism. Bull Eur Assoc Fish Pathol 5:8-9

Bell GR, Higgs DA. Traxler GS (1984) The effect of dietary ascorbate, zinc, and manganese on the development of experimentally induced bacterial kidney disease in sockeye salmon (Oncorhynchus nerka). Aquaculture 36:293-311

Brown LL, Evelyn TPT, Iwama GK, Nelson WS, Levine RP (1995) Bacterial species other than Renibacterium salmoninarum cross-react with antisera against $R$. salmoninarum but are negative for the $\mathrm{p} 57$ gene of $R$. salmoninarum as detected by the polymerase chain reaction (PCR). Dis Aquat Org 21:227-231

Brown LL, Iwama GK, Evelyn TPT, Nelson WS, Levine RP (1994) Use of the polymerase chain reaction (PCR) to detect DNA from Renibacterium salmoninarum within individual salmonid eggs. Dis Aquat Org 18:165-171

Bruno DW, Munro ALS (1986) Observations on Renibacterium salmoninarum and the salmonid egg. Dis Aquat Org 1:83-87

Bullock GL, Griffin BR, Stuckey HM (1980) Detection of Corynebacterium salmonis by direct fluorescent antibody test. Can J Fish Aquat Sci 37:719-721

Ecker RE, Lockhart WR (1959) A rapid membrane filter method for direct counts of microorganisms from small samples. J Bacteriol 77:173-176

Elliott DG, Barila TY (1987) Membrane filtration-fluorescent antibody staining procedure for detecting and quantifying Renibacterium salmoninarum in coelomic fluid of chinook salmon (Oncorhynchus tshawytscha). Can J Fish Aquat Sci 44:206-210

Evelyn TPT, Ketcheson JE, Prosperi-Porta L (1984) Further evidence for the presence of Renibacterium salmoninarum in salmonid eggs and for the failure of povidone-iodine to reduce the intra-ovum infection rate in water-hardened eggs. J Fish Dis 7:173-182

Evelyn TPT, Prosperi-Porta L, Ketcheson JE (1986) Experimental intra-ovum infection of salmonid eggs with Renibacterium salmoninarum and vertical transmission of the pathogen with such eggs despite their treatment with erythromycin. Dis Aquat Org 1:197-202

Fryer JL, Lannan CN (1993) The history and current status of Renibacterium salmoninarum, the causative agent of bac-

Responsible Subject Editor: D. Bruno, Aberdeen,

Scotland, UK terial kidney disease in Pacific salmon. Fish Res 17:15-33

Johnson GD, Davidson RS, McNamee KC, Russell G, Goodwin D, Holborow EJ (1982) Fading of immunofluorescence during microscopy: a study of the phenomenon and its remedy. J Immunol Meth 55:231-242

Jones SE, Ditner SA, Freeman C, Whitaker CJ, Lock MA (1989) Comparison of a new inorganic membrane filter (Anopore) with a track-etched polycarbonate membrane filter (Nuclepore) for direct counting of bacteria. Appl Environ Microbiol 55:529-530

Lee EGH, Evelyn TPT (1989) Effect of Renibacterium salmoninarum levels in the ovarian fluid of spawning chinook salmon on the prevalence of the pathogen in their eggs and progeny. Dis Aquat Org 7:179-184

Lee EGH, Gordon MR (1987a) Immunofluorescence screening of Renibacterium salmoninarum in the tissues and eggs of farmed chinook salmon spawners. Aquaculture 65: $7-14$

Lee EGH, Gordon MR (1987b) Development of a quantitative threshold dosage of Renibacterium salmoninarum in ovarian fluid which causes egg infection. Final Report, Project 2-11-327, prepared by B.C. Research, Vancouver, B.C., Canada, for Ministry of Agriculture and Fisheries, Victoria, B.C., Canada

Mitchum DL, Sherman LE (1981) Transmission of bacterial kidney disease from wild to stocked hatchery trout. Can J Fish Aquat Sci 38:547-551

Pascho RJ, Elliott DG, Mallett RW, Mulcahy D (1987) Comparison of five techniques for the detection of Renibacterium salmoninarum in adult coho salmon. Trans Am Fish Soc 116:882-890

Pascho RJ, Elliott DG, Streufert JM (1991) Brood stock segregation of spring chinook salmon Oncorhynchus tshawytscha by use of the enzyme-linked immunosorbent assay (ELISA) and the fluorescent antibody technique (FAT) affects the prevalence and levels of Renibacterium salmoninarum infection in progeny. Dis Aquat Org 12:25-40

Yoshimizu M, Ji R, Nomura T, Kimura T (1987) A falsepositive [sic] reaction in the indirect fluorescent antibody test for Renibacterium salmoninarum ATCC 33209 caused by a Pseudomonas sp. Scient Rep Hokkaido Salmon Hatchery $41: 121-127$

Zar JH (1974) Biostatistical analysis. Prentice-Hall, Inc, Englewood Cliffs, NJ

Manuscript received: December 11, 1996

Revised version accepted: March 12, 1997 